\title{
Minority young men's gendered tactics for making space in the city and at school
}

\section{Tolonen, Tarja}

2019-04-03

Tolonen , T 2019 , ' Minority young men's gendered tactics for making space in the city and at school ' , Gender and Education, vol. 31 , no. 3 , pp. 408-424 . https://doi.org/10.1080/09540253.2018.1496228

http://hdl.handle.net/10138/309130

https://doi.org/10.1080/09540253.2018.1496228

cc_by_nc_nd

acceptedVersion

Downloaded from Helda, University of Helsinki institutional repository.

This is an electronic reprint of the original article.

This reprint may differ from the original in pagination and typographic detail.

Please cite the original version. 


\section{Minority young men's gendered tactics for making space in the city and at school}

\section{Tarja Tolonen}

Phd, Docent, University lecturer,

Sociology, Faculty of Social Sciences, University of Helsinki.

taria.tolonen@helsinki.fi

P.O.Box 18 , Unioninkatu $35,2^{\text {nd }}$ floor,

Fi-00014 University of Helsinki, Finland

Author's Accepted Manuscript

To cite this article: Tarja Tolonen (2018): Minority young men's gendered tactics for making space

in the city and at school, Gender and Education, DOI: 10.1080/09540253.2018.1496228

\section{ABSTRACT}

This article draws on ethnographic fieldwork and interviews to explore young minority men's relation to school and city space in Helsinki from the perspective of their everyday experiences of racialisation in public spaces. The article uses the concept of 'power geometrical' relations of space by drawing on several research traditions, including youth and masculinity studies, studies on social space, racialisation and ethnicity, and human geography. The evidence shows the school to be an important site of local and national power geometry (Massey 1994), in which 'informal' and 'physical' spheres are dominated by peers and connect to streets and public spheres (Gordon, Holland, and Lahelma 2000; Gaskell 2008). The article shows how young minority men knew their place both in narrow local power geometries, and within the wider city and school spaces, exploring how they formed their own lived spaces (Lefebvre 1991), claimed their spaces and marked their spaces with diverse tactics (de Certeau 1988). Some tactics were socially open, such as making friends; some were very mobile, such as claiming their own urban spaces by mobility, or marking and 'hanging around'; and some involved big groups of friends, crowds, defence and embodied accounts.

\section{Introduction}

This article explores young minority men's relation to school space and city space in Helsinki from the perspective of the everyday experiences of racialisation in public spaces. The context of the article is multicultural eastern Helsinki, Finland. I mainly focus on eight young men between the ages of 13 and 17 from minority backgrounds, but also examine ethnographic fieldwork and interviews $(n=33)$ conducted locally, cited as 'power geometrical' relations. This provides a social background to the young minority men's tactics.

In their daily lives, these young men move between the spheres of school and the street and form their everyday social spaces there (see also Gaskell 2008; Robinson 2009). I show how the informal layers of the local public spaces of the street and school socially and spatially intertwine. Similar patterns of racialisation are repeated in both places, and the gendered tactics that the young men deploy also seem to recur. The interconnectedness of school and the public sphere is an important factor here. I examine this connection 
more closely by analytically dividing school into three levels: official, informal and physical (see Gordon, Holland, and Lahelma 2000; Tolonen 2001).

In the same vein as Gordon, Holland, and Lahelma (2000), I refer to three layers of school: the official, informal and physical. The official layer involves policies, teaching materials and the relationship to learning; the informal level consists of social and youth culture; and the physical level refers to the school building and the spaces formed by young people (see also Tolonen; Souto 2011). I focus on the informal and physical layers of the school, as I consider them to be a continuum that extends to the public spheres (Gaskel 2008; Thomson, Russel, and Simmons 2014).

The article draws on several research traditions, such as youth and masculinity studies and studies on social space, racialisation and ethnicity. It primarily draws on sociological discussions on gender, ethnicity and masculinities in the context of education and youth culture (Mac an Ghaill 1994; Kehily and Nayak 1997; Gordon, Holland, and Lahelma 2000; Phoenix and Frosh 2001; Nayak 2003; Rastas 2004; Gordon 2007; Manninen, Huuki, and Sunnari 2011; Godinho and Garas 2012). It also uses several terms from human geography, such as forming 'social space' (Lefebvre 1991) by employing 'tactics' to make this space (de Certeau 1988) in the context of local social relations and spaces, and 'local power geometries', a term from feminist geography used by Doreen Massey (1994).

The article thus describes the various gendered tactics of young men for making lived space within the local power geometries of informal school and the street (Massey 1994; de Certeau 1988 and Lefebvre 1991). I investigate these different tactics, and how the young men repeat them in everyday life in certain spaces, due to local 'everyday gendered and ethnic orders'. In the analytical part of the article, I explore the young men's everyday use of their 'lived space' (Lefebvre 1991; de Certeau 1988) through their display of certain gendered tactics, referred to as naming and knowing a place as well as marking, fearing and crowding a place.

\section{Racialised and gendered lives of young minority men - the school and the street}

Finland has relatively small populations of ethnic minorities and is a rather 'new' country in terms of immigration (only $5 \%$ of the population has an immigrant background, predominantly Russian, Estonian, Somali, and Afghan). Of the one million population of the Helsinki Metropolitan Area, the proportion of immigrants in 2012 was 11.5\%, and some districts had an immigrant proportion of $25 \%$ (Helsinki by Districts 2011). Although segregation by class or ethnicity in Finnish cities is not as distinct as in other countries (Spivak, Bass, and St. John 2011; Back, Shamser, and Bryan 2012; Teltemann, Darowski, and Windzio 2015), it is possible to find areas with larger minority populations than others (Helsinki by Districts 2011).

Social segregation among young people (see Kivijärvi 2014; Souto 2011) is developing in Finland, as in other countries (Back 1996; Sernhede 2007; Fangen 2010). The racialisation of young people who look 'different' is evident (see Tuan 1977, 16; Hautaniemi 2004; Rastas 2005). Thus, as elsewhere (Hollingworth and Williams 2009; Fangen 2010; Back, Shamser, and Bryan 2012; von Brömssen and Risenfors 2014), Finnish studies show that young people with minority backgrounds confront racialisation in the contexts of school, youth work, employment, and public spaces (Hautaniemi 2004; Rastas 2005; Souto 2011; Kivijärvi 2014; Peltola 2015). The above studies show that both young men and young women are sexualised as well as racialised in public spaces, but young minority men are particularly seen as a threat or danger, especially if they gather together in groups (Hautaniemi 2004; Rastas 2005; see also Tuan 1977, 16). More than other groups, boys with immigrant backgrounds report having bullied others, having been bullied by others, and having taken part in fights, often purely in self-defence (Räsänen and Kivirauma 2011, 66-74). 
Many masculinity studies claim that the threat of violence exists for most boys growing up, both majorities and minorities, in their everyday lives at school and on the street. Although this claimed threat is not an issue exclusive to minorities, for them it is often much more significant (Hautaniemi 2004, Rastas 2005). Many masculinity studies concern the norms, ideals and practices of young men's ability to fight and display their toughness in public spaces and in school while growing up. When boys attempt to gain popularity and higher status in their social group, in addition to being verbal and using humour, using their physicality is crucial (Mac an Ghaill, 1994; Kehily and Nayak 1997; Phoenix and Frosh 2001; Huuki, Manninen, and Sunnari 2010; Manninen, Huuki, and Sunnari 2011; Godinho and Garas 2012). Boys also encounter violence in public spaces such as school and the street. They may use it, restrain themselves from using it, avoid it, or be the object of it, but almost all confront it in varying situations in these places (Tolonen 1998; Huuki, Manninen, and Sunnari 2010; Huuki and Sunnari 2015). The ability to employ violence in the construction of social orders is considered a necessary yet double-edged skill. Although boys who use violence may dominate, they may not be liked as friends (Manninen, Huuki, and Sunnari 2011). These social and potentially physical encounters, as well as valuing the specific ways of being a man, occur particularly at the level of the informal school (Gordon, Holland, and Lahelma 2000).

I am fully aware that gender and ethnicity studies have histories of their own; the point of this article is that both concepts are socially constructed in everyday life, and at times reinforce each other (Anthias 2005). Gender, like ethnicity, is defined here as symbolically, culturally and hierarchically marked, as well as being an everyday action that is performed repeatedly, constituting the local gendered and ethnic orders of everyday life (for more on gender and class, see Butler 1999, Archer \& Yamachita 2003, Skeggs 2004; and on ethnicity, see Hall 1990; Essed 2002; Rastas 2005; Back, Shamser, and Bryan 2012). These orders are local, but formed through history, with their relations to domination and racialisation, as well as through current national political agendas. The concept of racialisation refers here to processes in which the discourse of race is used by collectives or individuals for purposes of labelling and exclusion (Rastas 2005, 149).

In this article, I continue the tradition of the studies of young men's masculinities, especially on the informal level of the school (Gordon, Holland, and Lahelma 2000; Tolonen 2001), but will extend my analysis to public spaces. The use of city space by young minority men is very mobile and fluid as they move through different spaces; however, social, physical and cultural restrictions are also experienced (Archer and Yamashita 2003, Fangen 2010). I analyse young racialised men's different tactics for using their space, their gendered performances such as dominance and respect, as well as physicality and fighting, but also other tactics such as making friends (Kehily and Nayak 1997; Manninen, Huuki, and Sunnari 2011). The focus is on the tactics of using the public spaces of the city and the informal school, which are seen here as being on a continuum. In the next section, I discuss space and tactics further, using them as analytical terms to explore the data.

\section{Tactics of using space in everyday life}

For years, youth cultures have been named after locations, or places - for instance, 'street corner society' (Whyte 1943, MacDonald and Shildrick 2007), 'urban youth cultures' (Lähteenmaa 1991), and girls' more private 'bedroom cultures' (McRobbie and Garber 2006/1975). Geography studies have naturally widely analysed space (Skelton and Valentine 1998; Nayak 2003; Tani 2015). Educational research has also explored school space in various ways (Gordon, Holland, and Lahelma 2000; Tolonen 2001; Souto 2011; von Brömssen and Risenfors 2014.) To study the different tactics of racialised young men in the informal school and city space, I next take a brief look at the discussion on space and place (cf. Farrugia and Wood 2017). 
Firstly, in everyday life, making space for oneself is an important part of performing gender at school and in public spaces. I assume here that the relationship of the young men to city space and the school space is deeply social. I adopt the term 'lived space' from Lefebvre in my present analysis of social everyday spatial practices. Lefebvre $(1991,31)$ states that 'every society produces its own space $(. .$.$) and spatial practises$ (...) along with its specific relation of production.' He argues (1991, 38-39) that there are three kinds of spatial existence: perceived space, conceived space and lived space. The first refers more to the physicality of space, and the second to the space planned and understood by experts. Here I mainly use the third aspect, in which lived space refers to the 'space of inhabitants and users' (Lefebvre 1991, 39; Robinson 2009, 508).

To study the everyday use of space, I focus on the young men's experiences of their everyday spaces at school and in the public sphere. Tuan (1977) explores the experiences and senses of places. He writes: 'In experience, the meaning of space often merges with that of place. "Space" is more abstract than "place". What begins as undifferentiated space becomes place as we get to know it better and endow it with value.' (Tuan 1977, 6)

Michel de Certeau (1988) discusses a similar tension between the terms 'space' and 'place', with space being more general, and place more particular and produced by its users:

'I shall make a distinction between space (espace) and place (lieu) that delimits a field. ---The law of the "proper" rules in the place: the elements taken into consideration are beside one another, each situated in its own "proper" and distinct location (...) in relation to place, space is like the word when it is spoken (...) In short, space is a practiced place. Thus the street geometrically defined by urban planning is transformed into a space by walkers.' (de Certeau 1988, 117)

De Certeau (1988) also uses the terms 'tactics' and 'strategies' to distinguish between the means of producing places and giving them meaning. Strategic uses of place are processed by institutions with power, by strategic planning and its rules. A tactic is something for users to reproduce in everyday life, with special reference to people in the position of the 'other'. De Certeau writes:

'I call a "strategy" the calculus of force-relationships which becomes possible when a subject of will and power (--- a city, a scientific institution) can be isolated from an "environment." A strategy assumes a place that can be circumscribed as proper. (...) I call a "tactic," on the other hand, a calculus which cannot count on a "proper" (a spatial or institutional localization) ---. The place of a tactic belongs to the other.' (de Certeau 1988, xix)

Here I follow de Certeau: I assume that in everyday life people use various places in tactical ways, and have intentions that are not necessarily deliberate but more habitual. Sandra Schmidt $(2011,22)$ claims that de Certeau (1988) uses terms such as 'strategies' and 'tactics' to distinguish between how places are structured and experienced, thus paralleling Lefebvre's (1991) conceived and lived space.

Although various authors give place and space different meanings, my point here is not to resolve this matter theoretically; rather, in this article I focus on the ways in which young men form everyday social and spatial life locally, with references to global (Massey 2005, 101). I adopt the lived space concept employed by Lefebvre (1991). Accordingly, space is something a person names, feels and uses for everyday purposes, not always noticing it, taking it for granted, yet also using it in a tactical (but not strategic) way, as defined by de Certeau (1998). I assume these tactics to be gendered repetitions, like Butler's performances (1999), but here I use the term 'tactics' instead of 'performances' to refer to the spatial formation of gender.

In addition to focusing on the everyday and tactical use of space, I highlight the relationality of space. Doreen Massey (1994) claims that places are networks of social relations, and uses the term 'power 
geometry', by which she means that groups and individuals are differently positioned in local networks, as well as in relation to each other. Through Massey's understanding, individuals, youth groups and spaces can be described as spatially and socially positioning each other within local gendered power geometries, which here describe youth groups and their local social and spatial relations (see Massey 1994, 121). Consequently, Massey considers the city a space that is deeply socially and relationally formed (see also Massey 2005).

These above terms are used in the analytical section of this article. The analysis involves a combination (see also Schmidt 2011) of the terms 'tactics' (de Certeau 1998) and 'lived space' (Lefebvre 1991), by introducing the varying (gendered) tactics for making lived spaces used by young minority men in local power geometries (Massey 1994).

\section{Methods, data and contexts}

This research is based on the multi-sited ethnographic (Kivijärvi 2014) work of data collections of young people's leisure-time practices'. The qualitative data gathered in Helsinki consisted of 33 ethnographic interviews (Sherman Heyl 2001) with young people aged 13 to 17, field observations, and discussions with teachers, youth workers, parents, and a policeman. Of the 33 interviewees, 23 were boys and 16 were girls; 12 were from minority groups, and the rest were from the white-majority population. My analysis particularly focuses on the interviews of eight young minority men from various backgrounds. When describing the local groups as the local power geometry, I refer to all the data of the 33 interviews and field notes.

The multi-sited fieldwork mainly took place in 2008-2009 at youth centres in Helsinki, as well as at a school in a suburban area of eastern Helsinkii. The suburban area in question is not a particularly poor or problematised district (Lindbäck and Sernhede 2013), even though it is reputed to have a high number of immigrant-background inhabitants. Eastern Helsinki in general still has a significantly lower immigrant population than most other European cities, accounting for only some 20-30\% of local school students, (Gaskell 2008; von Brömssen and Risenfors 2014; Teltemann, Darowski, and Windzio 2015). Helsinki statistics (Helsinki by Districts 2011) illustrate the characteristics of the area: a slightly younger population, more immigrants, lower educational and income levels, and a higher unemployment rate than most other Helsinki regions.

The eight boys I focus on in this article had experienced racialisation due to their backgrounds. These boys were very different from each other: some were born in Finland, with one or both parents being a nonFinn; others had moved to the country some years earlier. The size of their families varied, as did their religion. Some stated that school was easy for them, but for most, it was not. All liked sports, and a few boys wanted to become professional athletes. Some knew each other, but they did not comprise one local group of boys. Many had friends, or at least knew people, from a white-majority background, while others mainly had friends from minority groups. All but one had been in a fight during their school years; some at school and some on the street. Thus, these boys, hand-picked for the study, were not expected to come from similar immigrant backgrounds. However, despite their heterogeneity, they had similar experiences of racialisation (Runfors 2016). They had been treated as 'foreigners' and some had even been attacked for this reason.

During my fieldwork, I wondered why the participants would want to co-operate with me, positioned as an adult, blonde, middle-class woman (Ramazanogly and Holland, 2002, 112; Skeggs 2001). In part, their cooperation was for practical reasons: they received small gifts to thank them for their time, for instance sweets or cinema tickets. In addition, some interviews were conducted during school lessons, allowing 
them a break. I tried to gain their trust by assuring them of their anonymity and treating them with respect and as experts in the research themes of education and leisure-time activities (Skeggs 2001, 369). Further, sharing their experiences of racialisation through some of my own family relations (Rastas 2004) was important. I tried to avoid 'methodological nationalism', i.e. to not consider nation/state/society, as well as schools and other spaces, as self-evident and 'natural' places without change (Wimmer and Schiller 2002, 304; Gordon, Holland, and Lahelma 2000, 54). Rather, I spoke of both locality and school as deeply relational, changing and challenging places (Massey 1994).

Multiculturalism and equal rights are stipulated in official policy in Finland; in legislation on education, social policy and youth work. However, during the research period, the political climate became more populistic: arguments and strategies spread not only on the internet as hate speech, but also in national and local politics (e.g. Hatakka, Niemi, and Välimäki 2017; Second European Union Minorities and Discrimination Survey 2017). This multilevel racism was equally present at informal school and in public spaces during the field work, and I treated it as an important power geometrical political stratum of the background (Massey 1994; Massey 2005, 95).

This research followed the logic of a case study; instead of 'numbers', I focused on the variety of gendered tactics that the boys used, which I traced in the specific power geometrical contexts of the mobile and multiple spaces of cities (Massey 1994; Massey 2005, 95). In my analysis, I employed the following terms as analytical descriptions of the tactics used in making everyday lived spaces: 'naming' and 'knowing', 'marking', 'fearing' and 'crowding' (Robinson 2009). These are used as metaphorical descriptions of the processes of making 'lived space', i.e. 'spaces of inhabitants and users' (Lefebvre 1991, 39).

\section{Naming a space and knowing your place - social and spatial orders of the local power geometry}

First, local groups and their relations with the spatial are described here as local power geometry (Massey 1994), with reference to global relations (Massey 2005), including some practices of racialisation. Second, the minority boys with racialising experiences are the focus, as are their different tactics of using school and public spaces.

Both the majority and minority youths recognised the existing power geometry and knew how to read the local social and political 'map' (see also Frosh, Phoenix, and Pattman 2000; Archer and Yamashita 2003; Sernhede 2007; Hollingworth and Williams 2009; Johansson and Hammarén 2011; Lindbäck and Sernhede 2013). They knew how to relate this local power geometry to the political power geometry of Finland, which was becoming rather right-wing-populistic at the time of the research (see Hatakka, Niemi, and Välimäki 2017). Young people related in different ways to these politics and formed local/global power geometries in their neighbourhoods. Different combinations of local ties were born: for example, occasionally, young men played football together, forming teams called 'refugees' and 'Finns', thus creating friendly and ironic ties of 'neighbourhood nationalism' (Back 1996; Gordon 2007; Kivijärvi 2014; Haikkola 2011).

A similar type of combination of friendly ties were made daily at school. However, some students seemed hostile towards others. During the fieldwork I quickly learned that some white-majority young men with racialised opinions did not like a certain people, nor local square or subway station, as seen below.

TT: 'Do you have places in Helsinki that you don't like or that you're afraid of?'

Timiiii (a 15-year-old, white, working-class boy): 'Not really. But this subway station (gives a name), I don't like it. There are too many foreigners. Those with the wrong skin colour.' 
In this example, public space was marked through the tactic of naming a place using racist terms. The power geometry was established in marking the space by racialising a group. It also indicates how a street or public place acts as a familiar organiser of local social life (Robinson 2009). Similar phenomena emerged in the study of Norwegian Katrin Fangen (2010): she studied young Somali men who knew which part of the city of Oslo they socially belonged to and where they were not welcome.

The school space seemed to work in a similar way. This formation of power geometry was equally present at the local school. During the fieldwork at the school, I approached a 9th grade class to ask some students to participate in my research. Due to the school's multicultural catchment area, I expected to encounter multi-ethnicity in the classroom. However, most visible was a group of white-majority boys wearing pilot jackets and heavy boots, who looked like skinheads and seemed to have an influence on the social order of the class. Speaking with the teacher and the headmaster, I learned that this particular, almost exclusively white-majority class had a long history of attitude problems towards other, different-looking minority students, despite the teachers' active interventions (Souto 2011). These particular students tried to maintain their preferred order at the informal (student cultural) and physical (spatial) level (Gordon, Holland, and Lahelma 2000; Tolonen 2001) of the school, as is evident in the following.

Research Diary 4th of May 2009:

'I went to school this morning before 11 and hung around in the corridor where ninth graders congregate. Some students I knew were present, and one ninth-grade boy (a hockey player) was bullying a Somali boy, who was walking up the stairs. This bigger boy tried to prevent him, clearly wanting to make a show of bullying this smaller, darker boy. He mentioned something about the boy's big brother. A teacher came in and stopped this unfair wrestling. The bigger boy had a hesitant smile on his face, but I did not see the smaller one smiling. This was not a game between friends.

I noticed these white-majority boys, called 'Finnish boys' (in skinhead outfits with big boots, pilot jackets and shaved heads) upstairs, and downstairs there were more immigrant children and their friends. Although this social line was not always kept, the different groups of young people seemed to gather in different places.'

During my several visits to this school, I perceived a seemingly clear social and physical division of the school space among these students. Although the official school level, that is, the education system, provides free and equal education for all, the school was informally physically and socially divided into 'upstairs' and 'downstairs' (see also Gordon, Holland, and Lahelma 2000; Tolonen 2001). Similar phenomena have been observed within school classes (Souto 2011). As in the Swedish study of an 'immigrant corner' by Kerstin von Brömssen and Signild Risenfors (2014), students from immigrant backgrounds in this school used their corner downstairs as a strong place for identity work, a place to explore the importance of being 'a foreigner' or of being treated as one.

Several kinds of tactics were at play in the immigrant corner of the school I studied: it was a socially loud place, where some boys concentrated on having fun (von Brömssen and Risenfors 2014). There seemed to be more boys than girls there, but it was made clear that everyone was welcome. The boys I interviewed considered this flexible and relaxed style important. For example, Khadar, a 15-year-old boy with a Somalian background, said he valued friends who were not aggressive, who did not want to fight and who had a good sense of humour (see Kehily and Nayak 1997; Huuki, Manninen, and Sunnari 2010).

Arif, a 15-year-old boy with a Turkish background was also part of this immigrant corner group. Like many other members of this group, he claimed he had all kinds of friends; however, many preferred their friends to be of the same gender, social class, and at times, from the same religious or ethnic background, with a similar level of school success (Aaltonen et al. 2011; Souto 2011; Tolonen 2013; Kivijärvi 2014). 
TT: 'What kind of groups are there in your school?'

Arif: 'There are the heavy rockers; there are those who don't study and those who do; there are the ordinary ones; and there are the foreigners [immigrants] and Finns, and I am mostly with the foreigners. Then there are the racist ones; then those who do sports, and the ones who play with their computers and talk about them --- I belong to the foreigners, and those who study.'

So Arif knew his place in relation to school success (and official school and education) as well as in relation to informal school and ethnicity. He stated that he wanted to succeed at the official school level and not just gain masculine respect within the informal, street-based student culture (Manninen, Huuki, and Sunnari 2011).

At school, Arif deliberately used the tactic of friendship to form a social space: in his interview, he repeated that even though his closest friends were from his own ethnic group (of boys), he wanted to be friends with everyone, and included everyone willing to visit or stay in their immigrant minority space. He told of playing football with a friend from a 'Finnish' white-majority background, and emphasised that he had friends from many social groups.

Arif: 'I want to be friends with everyone who wants to be my friend; I don't distinguish between people; a friend is a friend (...) We don't have that many racists in our school, but outside there are more. If I'm with immigrants, they come and call us names. Then there may be some pushing and shoving, but not really a fight. Then someone comes and interrupts it.'

Even though Arif used the tactic of friendship to create his lived space within the local power geometry, he recognised the social order and the divided informal school space. He was socially flexible, and still he knew his place in this order. In his narratives, the school space and the street existed closely side by side, reflecting each other. The young men could all recognise and name different lived spaces (Lefebvre 1991) and local power geometries (Massey 1994) due to their own classed, gendered and ethnic positions and experiences. The young men experienced places and created spaces differently, as they cut across and intersected each other, sensing the local power geometries (c.f. Massey 1994, 3; Massey 2005; 95; Gaskell 2008).

\section{Marking, fearing and crowding a space}

Like the other 33 young participants in the Helsinki study, the eight minority boys were also fond of the suburban places in which they lived and spent much of their leisure time making spaces and identifying with the local sites. This involved forming lived spaces of their own: they walked and talked in the streets; used the library, youth centres or coffee shops; or visited each other's homes (c.f. Shildrick 2006; Robinson 2009). They used the city space in various ways and could read each other's tactics for making and marking lived spaces. The tactics for using the local shopping centre differed: some used it daily as a place to 'hang around' in, while for others, being in the streets or at the shopping centre was a sign of 'doing nothing', or 'a way of getting in trouble with the law' (see also Robinson 2009; Tani 2015; Kivijärvi 2014). A recognised local power geometry seemed to exist (Massey 1994): an everyday spatial social order among the local youth including classed, gendered and ethnic tactics for marking a lived space of one's own, or for some, for avoiding it (Tolonen 2017).

Many of the minority young men had particularly mobile lives. They travelled daily from local premises and streets to sports facilities, hobbies or to the city centre to 'hang around' (see also Tani 2015, Massey 2005, 95). The young men would hardly ever admit to being afraid in the city spaces. Still they used various tactics to secure their lived spaces. At times they crowded a space: they formed 'communities of difference' 
(Vestel 2004; Fangen 2010,) in which they could feel safe with many other young men from various backgrounds.

Some, like 15-year-old Henry with a Finnish-African background, felt safe hanging around with friends with Finnish backgrounds (see also Rastas 2005). For him, the main tactic was to avoid conflicts, to be surrounded by his friends, and not to move around alone. This 'crowding' diminished the risk of being challenged physically. Further, he had adopted the tactic of being extra polite, as the following interview extract reveals.

Henry: '[I haven't been challenged] very often. I'm quite big physically. And besides, I avoid situations like that. I always try to be very polite to people, that's also the reason I haven't been challenged to fight (...) No-one has said anything to me [unpleasant racialisation], not much (...) I've always kept my friends close.'

Many minority young men had pleasant experiences of mobility in the city space, otherwise this would not have been so popular among them. For some, this mobility was an important basis of their identity. For example, one 15-year-old boy, Ollie, with a Mediterranean background, was interested in graffiti art and skate- and snowboarding. His social tactics included not only mobility in the local or city area but also travelling abroad, and he claimed he had hundreds of friends, both girls and boys, both Finns and 'foreigners'.

Ollie: 'I have nothing against anyone. I have friends who are like heavy rockers, or listen to rap music, black people, people from different countries.'

Many boys used tactics of crowding and friendships to avoid 'fearing a space'. However, when asked if the boys felt fear in unpleasant situations or places, most mentioned verbal or physical threats, or fights they had been in. The boys had experienced physical threats on school premises and in the street, and these experiences often merged. The boys commonly mentioned having been in a fight when younger. Sometimes the fighting was a tactic for getting to know each other and earning respect (Manninen, Huuki, and Sunnari 2011). Some of the interviewees had earlier fought with people who later became their friends, like Abshir, a 16-year-old Somalian boy.

Abshir: 'Well, I used to have fights with my friend Hanad. We met in the city centre and fought. Then we got to know each other. And he came to our school and we became good friends.'

The threats were often posed by other young men, but also by adult men. The abovementioned Ollie revealed he was afraid of security guards.

Ollie: 'I've always liked graffiti art (...) Well I have lots of friends who do it as well (...) once I saw my friend (...) all beaten up by the guards, they had caught him in the woods.'

In addition, two of the eight boys, Abshir and Mahad, had been seriously attacked by strangers, adult men. This type of violence occurred in public spaces and not at school. However, the experience of racialisation was a continuum. Below is an account by Mahad, 15 years old, with a Somali background, of his racialised experiences at school and in a public space. Connections exist between these different lived public spaces, one open and one institutional, as well as the masculine reputations and tactics inherent in them (Gaskell 2008).

Mahad: 'Those skinheads do (use the N-word). At school. In seventh grade. Not anymore. And if they don't shut up you ask more people (...) that has happened. A gang fight. In the centre, at the beach. I was there too. We walked by, they just challenged us. The heavy metal guys. All the immigrants together fought against the skins and heavy rockers (...) When I first came here, to this school in seventh grade, I was a new student and everyone said the $\mathrm{N}$-word to me. I fought with everyone, but not anymore. Everyone is nice to 
me (...) I got this position, no one bullies me anymore (...) It's happened a hundred times. They (at school) don't come and challenge me anymore. But I get annoyed (...) if, for example they do say the N-word. Then I lose my temper and go for it.'

TT: 'Were there any ways to show your position other than fighting?'

Mahad: 'No, I don't think so (...) But I don't think they say this [N-word] now, since there are so many of us, a big bunch of people.'

Forming lived spaces in public, safe 'communities of difference' (Fangen, 2010, Vestel 2004) - or 'a big bunch of people', as Mahad called it - seemed to be an important way to ensure physical security, as mentioned earlier by Henry. In addition to crowding the space, the minority boys felt they had to employ this kind of physical masculine tactic of fighting to gain respect both on the street and at school (see Manninen, Huuki, and Sunnari 2011; Huuki and Sunnari 2015). Mahad, who employed the tactic of keeping friends around, had also been attacked while alone, as he recounts below.

TT: 'Is there a sense of safety when you're in a big group of people? Would you dare go there [the same square] in the evening by yourself?'

Mahad: 'Oh yes (...) But once someone beat me up there. A big man, a kind of skinhead, 50 years old or so. He came out of a bar (...) walked right towards me, lifted me up and hit me. I asked why he did it. He said he didn't know. Then I called my father and he asked who it was, and I told him. He was just running away (...) He got into a car and left. Maybe he had planned it, I don't know.'

This physical attack changed the young man mentally and socially. He trusted and contacted his father, but did not report it to the police. His gendered tactics of using physical power underwent a change (see also Huuki \& Sunnari, 2015).

TT: 'Terrible. I'm truly sorry. Does it affect where you go now, and what you do?'

Mahad: 'No, no. I was a coward then, I didn't dare do anything. But since I got beaten up I became a tough guy (...) I won't let anyone touch me, beat me up. Like yesterday, I was in a shop queue and a drunken man got in front of me. I told him I was in the queue and asked if he could please move. He said no. I told him that I would count to three, and that I meant it. Then he left, kind of laughing (...) You know, I can't control myself if someone calls me the $\mathrm{N}$-word (...) He has to stop and apologise to me.'

TT: 'Why do you think it hurts you so much personally? Can't you just tell them they're stupid and walk away or something?'

Mahad: 'I'm nobody's slave. This word, somehow (...) I cannot explain it.'

Anoop Nayak writes about racist name-calling in the classroom. He claims that young black people can call white students names such as white duck or ice cream; as these names do not refer to a history of slavery, imperialism, apartheid, and discrimination (see Nayak 2003, 149-151), they do not trigger feelings of humiliation and devaluation (Frosh, Phoenix, and Pattman 2000). Such incidents of name-calling experienced by visible minority youth, especially those with darker skin, take place in both Finnish schools and public spaces (Hautaniemi 2004; Rastas 2005; Souto 2011). For the young men in this study, simply learning the official school subjects and rules was not enough (see Gordon 2007). The informal and physical layers were significant and intertwined: relevant issues for coping and forming lived spaces at school included becoming streetwise and learning the 'right' tactics, that is, ways in which to negotiate as a means of survival regarding respect, and at times the use of violence (Gaskell 2008, 234; Manninen, Huuki, and Sunnari 2011). 
Mahad's story was the most dramatic of the above interview excerpts. His case describes the attempts of forming free and non-limited lived space in the city, and the tactics he was forced to use in order to defend himself in a physical way or with the tactical help of a 'big bunch of people', a crowd (Vestel 2004; Fangen 2010). Mahad told a 'transition' story about how his masculine resources developed so that he could defend himself, and how he consequently became a physical, independent citizen who, as a black man, was nobody's slave and had a strong sense of self-worth both at school and in other public spaces.

Not all the young men from minority backgrounds had had such harsh racialised experiences, but most had experienced name-calling, and had consequently reacted, at school. As Sebastian, a 15-year-old boy with a Mediterranean background, described: 'At the moment, I get along with everyone at school (...) when we were younger, we called each other names and then there were fights.'

Others with less dramatic experiences of racialisation had also been targets of name-calling or bullying, which required verbal defence to maintain their freedom of space. As well as befriending former adversaries, like Mahad; being friends with everyone, like Ollie and Arif; or looking for friends ('communities of difference') to protect themselves from outsiders, like Henry and Mahad, these boys used other tactics to secure their peaceful lived spaces. Some, like Abshir, avoided places such as the city centre because they were not interested in fighting. Most minority background boys also kept clear of those who used alcohol and other substances, to avoid trouble. At school they created lived spaces, such as 'immigrant corners' (von Brömssen and Risenfors 2014) or 'communities of difference' (Vestel 2004, Fangen 2010,) within informal school.

The connection between lived city space and school space in the young men's stories above is compelling. According to Carol Gaskell (2008), school acts as a space in which respect can be fought over and negotiated, a space in which the dynamics of respect can be witnessed and redistributed by peers (Manninen, Huuki, and Sunnari 2011). These processes can be seen in the present research: the boys had experienced racialisation at school and in the street, which felt like a continuum in their lives. They had adopted similar tactics both at school and on the street; some tried to be friends with as many people as possible and use their social groups while forming lived spaces in school and in the city space, and others found the tactic of fighting to be useful. In the everyday lives of these young men, the encounters in the school space were analogous to those in the city space. The power geometries of the school and the street constituted a local, social and spatial continuum (Massey 1994). In addition, these local power geometries seem to constitute a continuum of the political power geometry in Finland at the time (see Massey 2005).

\section{Conclusions}

As Runfors (2016) claimed, it is important to methodologically explore the racialisation experiences of young men from different backgrounds, not just from one ethnic group, I claim that it has been equally important to examine the spatial tactics (de Certeau 1998) and similarities within the power geometries (Massey 1994) of both the street and school. Looking at both lived spaces (Lefebvre 1991) enabled me to find similar racialised experiences and patterns of the tactics repeated by boys who are visibly 'different' (c.f. Tuan 1977, 16; Rastas 2005).

The school is an important site of local as well as national power geometry. It is a nationally regulated space in terms of education and employment, but also of social control and educational policy (Gordon, Holland, and Lahelma 2000). However, a school's 'informal' and 'physical' spheres are often more fluid, and dominated by local peer culture. This is where other kinds of tactics are employed, where the value of one's self is formed (Skeggs 2004), and where the most physical acts and intimate respect for one's self are 
fought over publicly (Manninen, Huuki, and Sunnari 2011). In addition, these local power geometries have a relation to political power geometries, e.g. the political atmosphere of the time.

I have argued that the young minority men knew their place in these, at times, narrow local and political power geometries, but that they also used the city and school spaces, formed their own lived spaces, claimed their spaces, and marked their spaces through diverse tactics. Some tactics were socially open, such as making friends; some were very mobile, such as claiming their own urban spaces by moving, marking or 'hanging around'; and others involved large groups of friends, crowds, defence, and embodied accounts. To avoid 'fearing' the space, they reached for 'crowding' the space with social and sometimes physical tactics.

Being able to use different tactics was not only lived and experienced, but also material and embodied (Massey 2005, 185). Most of the boys lived ordinary, peaceful lives. However, almost all of them had experienced some kind of racialisation and embodied incidences: many had been in a fight at one time or another, often initiated by outsiders (Räsänen and Kivirauma 2011, 66-74). Due to the need for respect and the physical struggle to socially exist in city space and school space, the young men learned to earn social respect through their bodies and their masculine resources of self-defence. These experiences and continuances in public spaces and at informal school seemed to affect the boys' feelings of belonging, sense of security and sense of embodiment, and possibly their school performance.

Similar ways of displaying masculinities through embodiment can be seen in many schools and public spheres. State institutions work in ways that are different to the street, but the informal level of the school socially resembles the local street culture. Similar tactics can be used in both contexts, and this article has been highlighted the fact that for young minority men, the experiences and tactics used in one place (school) affect their experiences and tactics used in the other (the street). This also shows how subtly and fluidly local power geometries (Massey 1994; 2005, 13) tie these different social spaces together, and how they are inscribed in the bodies of young minority men (Skeggs 2004, 13), framed by the local as well as the national balance of the political power geometry (Massey 2005, 101).

\section{Disclosure statement}

No conflict of interests

Funding: Project Young people's leisure time funded by the Youth Research Network, and the Material and cultural formation of family project funded by the University of Helsinki.

Acknowledgements: In addition thanking colleagues who worked in these abovementioned projects, I would like to give special thanks to colleagues Elina Lahelma (University of Helsinki), and Sinikka AapolaKari and Lotta Haikkola (Youth research network) of commenting this particular manuscript in detailed manner.

\section{References:}

Aaltonen, S., Kivijärvi, A., Peltola, M., and Tolonen, T. 2011. "Ystävyydet" [Friendships]. In Annettu, otettu ja itse tehty. Nuorten vapaa-aika tänään [Given, taken, self-made. Youth and Leisure Today] edited by M., Määttä, and T. Tolonen, 29-55. Helsinki: Youth Research Network, 112. 
Anthias, F. 2005. "Social Stratification and Social Inequality: Models of Intersectionality and Identity". In Rethinking Class. Culture, Identity and Style edited by F. Devine, M. Savage, J. Scott, and R. Crompton, 2445. New York: Palgrave Macmillan.

Archer, L., and Yamachita, H. 2003. "Theorising Inner-city Masculinities: 'Race', class, gender and education." Gender and Education 15 (2): 115-132.

Back, L. 1996. New Ethnicities and Urban Culture: Racisms and Multiculture in Young Lives. London: Routledge.

Back, L., Shamser, S., and Bryan, S. 2012. "New hierarchies of belonging." European Journal of Cultural Studies 15 (2): 139-154.

Butler, J. 1999. Gender Trouble. Feminism and the Subversion of Identity. New York and London: Routledge. de Certeau, M. 1988. The Practice of Everyday Life. Berkeley, Los Angeles, London: University of California Press. https://chisineu.files.wordpress.com/2012/10/certeau-michel-de-the-practice-of-everyday-life.pdf (read 3.12. 2017)

Essed, P. 2002. "Everyday Racism: A new Approach to the Study of Racism." In Race Critical Theories, edited by P. Essed, and D.T. Goldberg, 176-194. Malden USA and Oxford, UK: Blackwell.

Fangen, K. 2010 "Social Exclusion and Inclusion of Young Immigrants: Presentation of an Analytical Framework." Young - Nordic Journal of Youth Research 18 (2): 133-156.

Farrugia, D. and Wood, B.E. 2017. "Youth and Spatiality: Towards Interdisciplinarity in Youth Studies." Young - Nordic Journal of Youth Research 25 (3): 209-218. https://doi.org/10.1177/1103308817712036.

Frosh, S., Phoenix, A., and Pattman, R. 2000. "But It's Racism I Really Hate': Young Masculinities, Racism and Psychoanalysis." Psychoanalytic Psychology 17 (2): 225-242.

Gaskell, C. 2008. "'But They Just Don't Respect Us': young people's experiences of (dis)respected citizenship and the New Labour Respect Agenda." Children's Geographies 6 (3): 223-238.

Godincho, S., and Garas, D. 2012. "(Re) Configuring masculinities in an ethno-centric Australian community school: complexity and contradictions." Gender and Education 24 (1): 83-99.

Gordon, T., Holland, J., and Lahelma, E. 2000. Making Spaces: Citizenship and Difference in Schools.

Houndsmills et al.: MacMillan Press Ltd.

Gordon, T. 2007. "Urban Citizenship." In International Handbook of Urban Education, edited by W.T. Pink, and G.W. Noblit, 447-462. Dordrecht: Springer.

Haikkola, L. 2011. "Transnational and Local Negotiations of Identity: Experiences from Second Generation Young People in Finland", Nordic Journal of Migration Research 1 (3): 156-165.

Hall, S. 1990. "Cultural Identity and Diaspora." In Identity, Community, Culture and Difference, edited by J. Rutherford, 222-237. London: Lawrences and Wishart.

Hatakka, N., Niemi M. K., and Välimäki, M. 2017. "Confrontational yet submissive: Calculated ambivalence and populistic parties' strategies of responding to racism accusations in the media." Discourse and Society 19 (1): 2-19.

Hautaniemi, P. 2004 Pojat! Somalipoikien kiistanalainen nuoruus Suomessa [Lads! The contested childhood of Somali youngsters in Finland] Helsinki: Youth research network, 41. 
Helsinki by Districts. 2011. Report published by City of Helsinki Urban Facts, City of Helsinki. http://www.hel.fi/hel2/tietokeskus/julkaisut/pdf/11_03_30_Tilasto_hki_alueittain_2011_Tikkanen.pdf (read 21.4.2015)

Hollingworth, S., and Williams, K. 2009. "Constructions of the Working-class "Other" among Urban, White, Middle-class Youth: "Chavs", Subculture and the Valuing of Education." Journal of Youth Studies 12 (5): 467-482.

Huuki, T., Manninen, S., and Sunnari, V. 2010. "Humor as a resource and strategy for boys to gain status in the field of informal school." Gender and Education 22 (4): 369-383.

Huuki, T., and Sunnari, V. 2015 "Standing by... standing off - troublesome companion in the relationships of school boys." Gender and Education 27 (5): 555-574. DOI: 10.1080/09540253.2015.1069798

Johansson, T., and Hammarén, N. 2011. "The art of choosing the right tram: Schooling, segregation and youth culture." Acta Sociologica 54 (1): 45-59.

Kehily, M. J., and Nayak, A. 1997. "Lads and laughter. Humor and the production of heterosexual hierarchies." Gender and Education 9 (1): 69-87.

Kivijärvi, A. 2014. "Interethnic Affiliations and Everyday Demarcations of Youth in Finland. Empirical Glances through Multisited Interviews and Observations." Young - Nordic Journal of Youth Research 22 (1): 67-85.

Lefebvre, H. 1991. The Production of Space. Oxford: Blackwell.

Lindbäck, J., and Sernhede, O. 2013. "Divided city - divided school: Upper secondary school students and urban space." In Youth and marginalization. Young people from immigrant families in Scandinavia, edited by G. Gudmunsson, D. Beach, and V. Vestel, 155-179. London: Tufnell Press.

Lähteenmaa, J. 1991. Hip-hoppareita, lähiöläisiä ja kultturelleja: nuorisoryhmistä 80-luvun lopun Helsingissä. [Hiphoppers, suburban youth and youth with cultural capital]. City of Helsinki, Center for Youth Work, Publications 1991,1.

Mac an Ghaill, M. 1994. The Making of Men: Masculinities, sexualities and schooling. Buckingham and Philadelphia: Open University Press.

MacDonald, R., and Shildrick, T. 2007. "Street Corner Society: Leisure Careers, Youth (Sub)culture and Social Exclusion." Leisure Studies 29(3): 339-355.

Manninen, S., Huuki, T., and Sunnari, V. 2011. "'Earn Yo' Respect! Respect in the Status Struggle of Finnish School Boys." Men and Masculinities 14 (3): 335-357.

Massey, D. 1994. Space, place and gender. Cambridge: Polity Press.

Massey, D. 2005. For Space. London: Sage Publications.

McRobbie, A., and Garber, J. 2006/1975, "Girls and subcultures", in Resistance through rituals: youth subcultures in post-war Britain, edited by S. Hall, T. Jefferson (2nd ed.), 172-184. New York, US Oxford, UK: Routledge, OCLC 489757261. ISBN 9781134346530.

Nayak, A. 2003. Race, Place and Globalization. Youth Cultures in a Changing World. Oxford: Berg.

Phoenix, A., and Frosh, S. 2001 “Positioned by 'Hegemonic' Masculinities: A study of London Boy's Narratives of Identity." Australian Psychologist, 36 (1): 27-35. 
Peltola, M. 2015. "Respectable families: Discourses on family life, ethnic hierarchies and social positioning." Ethnicities 16 (1): 22-39. https://doi.org/10.1177/1468796815587008

Ramazanogly, C. and Holland, J. 2002. Feminist Methodology: Challenges and Choices. London: Sage Publications.

Rastas, A. 2004. “'Am I Still 'White'? Dealing with the Colour Trouble”, Balayi: Culture, Law and Colonialism 6: 94-106.

Rastas, A. 2005. "Racializing Categorization Among Young People in Finland." Young: Nordic Journal of Youth Research 13 (2): 147-166.

Robinson, C. 2009. "Nightscapes and leisure spaces: an ethnographic study of young people's use of free space." Journal of Youth Studies 12 (5): 501-514.

Runfors, A. 2016. "What an ethnic lens can conceal: the emergence of a shared racialised identity position among young descendants of migrants in Sweden", Journal of Ethnic and Migration Studies 42 (11): 18461863, https://doi.org/10.1080/1369183X.2016.1153414.

Räsänen, M, and Kivirauma, J. (2011) "Oppilaana monikulttuurisessa koulussa” [As a student in multicultural school]. In Vieraina koulussa? Monikulttuurinen koulu oppilaiden, vanhempien ja rehtoreiden kokemana [Stangers at school? Multicultural school experienced by students, parents and head masters], edited by K. Klemelä, A. Tuittu, A. Virta and R. Rinne, 35-95. University of Turku, Educational Faculty, A:11.

Schmidt, S. 2011. "Theorising place. Students' Navigation of Place Outside the Classroom." Journal of Curriculum Theorising 27 (1): 20-35.

Sernhede, O. 2007. "Territorial stigmatization, Hip hop, and informal schooling." In International Handbook of Urban Education, edited by W.T. Pink, and G.W. Noblit, 463-479. Dordrecht: Springer.

Second European Union Minorities and Discrimination Survey 2017. European Union Agency for Fundamental Rights. http://fra.europa.eu/en/publication/2017/eumidis-ii-main-results, read 12.12. 2017.

Sherman Heyl, B. 2001. "Ethnographic interviewing." In: Handbook of Ethnography, edited by P. Atkinson, A. Coffey, S. Delamont, J. Lofland and L. Lofland, 369-383, Sage, London et al.

Shildrick, T. 2006. "Youth culture, subculture and the importance of neighbourhood." Young - Nordic Journal of Youth Research 14 (1): 61-74.

Skeggs, B. 2001. "Feminist Ethnography." In: Handbook of Ethnography, edited by P. Atkinson, A. Coffey, S. Delamont, J. Lofland and L. Lofland, 269-383, Sage, London et al.

Skeggs, B. 2004. Class, Self, Culture. London and New York: Routledge.

Skelton, T. and Valentine, G. eds. 1998. Cool Places. Geographies of youth cultures. London: Routledge.

Souto, A-M. 2011. Arkipäivän rasismi koulussa: Etnografinen tutkimus suomalais-ja maahanmuuttajanuorten suhteista Joensuussa [Everyday Racism in School. An Ethnographic Study of Group Relations between Finnish and Immigrant Youths]. Helsinki: Youth research network, 110.

Spivak, A.L., Bass, L.E. and St. John, C. 2011. Reconsidering Race, Class, and Residential Segregation in American Cities, Urban Geography, 32:4, 531-567, DOI: 10.2747/0272-3638.32.4.531, read 5.12. 2017

Tani, S. 2015. "Loosening/tightening spaces in the geographies if hanging out." Social \& Cultural Geography 16(2): 125-145. 
Teltemann, J., Dabrowski S. and Windzio, M. 2015. Räumliche Segregation von Familien mit Migrationshintergrund in deutschen Großstädten: Wie stark wirkt der sozioökonomische Status? [Spatial segration of families with migration background in big cities in Germany] Kölner Zeitschrift für Soziologie und Sozialpsychologie 67(1): 83-103.

Thomson, R., Russel, L., and Simmons, R. 2014. "Space, place and social exclusion: an ethnographic study of young people outside education and employment." Journal of Youth Studies 17 (1): 63-78.

Tolonen, T. 1998. "Everybody Thinks I'm a Nerd". Schoolboys' Fights and Ambivalences about Masculinities." Young: Nordic Journal of Youth Research 6(3): 4-18.

Tolonen, T. 2001. Ääni, tila ja sukupuolten arkiset järjestykset. Nuorten kulttuurit koulussa. [Youth cultures at school: voice, space and gender], Helsinki: Gaudeamus and Youth Research Network.

Tolonen, T. 2013. "Youth cultures, lifestyles and social class in Finnish contexts." Young: Nordic Journal of Youth Research 21 (1):55-75.

Tolonen, T. 2017. "Young People and Local Power Geometries in Helsinki. The Intertwining of Social Class, Gender and Ethnicity in Public Spaces." In Second International Handbook of Urban Education. Springer International Handbooks of Education, edited by W. Pink, G. Noblit, 755-774. Dordrecht: Springer.

Tuan, Y-F. 1977. Space and place. The perspectives of experience. London: Edward Arnold Publishers limited.

Vestel, V. 2004. Community of Differences-Hybridization, Popular Culture and the Meaning of Social Relations among Multicultural Youngsters in 'Rudenga', East Side of Oslo. Oslo: NOVA.

von Brömssen, K., and Risenfors, S. 2014. "The 'Immigrant Corner': a place for identification and resistance." European Educational Research Journal 13 (6): 632-645.

Wimmer, A., and Glick-Shiller, N. 2002. "Methodological Nationalism and Beyond: Nation-State Building, Migration and the Social Sciences" Global Networks 4 (2) 301-334.

Whyte, W. F. 1943. The Street Corner Society. The social structure of an Italian slum. Chicago and London: The University of Chicago Press, Fourth Edition.

\footnotetext{
'This research work is connected to the two research projects: Young people's leisure time conducted by the Youth Research Network, and the Material and cultural formation of family project conducted by the University of Helsinki. ii This research project received research permission, including ethical approval, from the City of Helsinki.

iii iii All names of the persons, places and institutions referring to the data have been anonymised.
} 